\title{
PERUBAHAN KONDISI PSIKOSOSIAL DAN SPIRITUAL PADA KORBAN PTSD (POST TRAUMATIC STRESS DISORDER) PASCA BANJIR BANDANG DI KOTA GARUT JAWA BARAT
}

\author{
Suwarningsih $^{1)}$, Ilah Muhafilah' ${ }^{2}$, Tri Mulia Herawati ${ }^{3}$ \\ Program Studi S1 Keperawatan Universitas MH.Thamrin \\ suwarningsih41@gmail.com
}

\begin{abstract}
ABSTRAK
Bencana khususnya banjir memberikan dampak pada individu dan keluarga yaitu terganggunya masalah fisik dan mental dikarenakan peristiwa traumatis. Banjir bandang menimbulkan kerugian dan penderitaan yang mempengaruhi beberapa aspek diantaranya psikososial dan spiritual yang menimbulkan gangguan stress pasca trauma berkelanjutan atau Post Traumatic Stress Disorder. Penelitian ini bertujuan untuk mengidentifikasi hubungan aspek psikososial dengan aspek spiritual pada kejadian Post Traumatic Stress Disorder korban pasca banjir bandang di wilayah kota Garut Jawa Barat, dengan menggunakan desain metode kuantitatif non eksperimen dengan pendekatan cross sectional. Sampel yang digunakan sebanyak 150 kepala keluarga. Hasil penelitian yang didapat yaitu adanya hubungan yang signifikan antara aspek psikososial dengan aspek spiritual, dengan nilai $\mathrm{p}=0.011$. Saran pada penelitian ini yaitu memberikan Psikososial Support Program sebagai solusi pemulihan aspek psikososial dan spiritual pada masyarakat pasca bencana.
\end{abstract}

Kata Kunci: Psikososial, Spiritual dan Banjir Bandang

\section{PENDAHULUAN}

Wilayah Indonesia menurut morfologis, geografis dan perubahan iklim dapat menjadi faktor pendukung terjadinya bencana. BNPB (2016) menyatakan sampai dengan pertengahan tahun 2016, lebih dari 1.118 kejadian bencana terjadi di Indonesia dengan rata-rata kejadian dalam satu bulan sebanyak 124 kali bencana atau diperkirakan 4 kali kejadian setiap harinya. Data BNPB tahun 2017 menjelaskan sebanyak 654 kejadian bencana alam meliputi banjir, longsor dan putting beliung.

Bencana merupakan serangkaian kejadian atau peristiwa yang berdampak pada masalah fisik maupun psikologis dan dapat menyebabkan kerusakan serius sehingga mengganggu fungsi atau sistem pada komunitas dan sosial tertentu serta menimbulkan kerugian pada manusia dan lingkungan (Peraturan Pemerintah RI, No.21 Tahun 2008). Sejak tahun 2006 sampai dengan 2016 bencana banjir menjadi peringkat pertama dengan angka kejadian dan jumlah korban tertinggi. Presentasi insiden kejadian bencana banjir yaitu $45 \%$ dari beberapa kejadian bencana lainnya, sedangkan jumlah korban yang meninggal sebanyak 1.991 orang (BNPB, 2016). Periode 2012 sampai dengan Maret 2017 terdapat 31.5\% kejadian bencana banjir di Indonesia (BNPB, 2017).

Bencana khususnya banjir bandang memberikan dampak pada individu dan keluarga yaitu terganggunya masalah fisik dan mental dikarenakan peristiwa traumatis. Dampak lainnya yaitu menimbulkan kerugian dan penderitaan sehingga mempengaruhi aspek-aspek kehidupan baik lingkungan dan sosial (Keliat, et al, 2011). Penelitian Ilyas tahun 2008 menjelaskan bencana meninggalkan dampak bagi korbannya dari aspek fisik, material, ekonomi, psikologis, sosial dan spiritual.

Terdapat empat aspek utama pada manusia yang dapat ditangani saat terjadi dan pasca bencana yaitu fisik, mental, spiritual dan sosial, semuanya itu saling berkaitan (Stuart, 2013). Terganggunya kondisi mental yang disebabkan karena kehilangan harta benda dan keluarga merupakan salah satu dampak psikologis akibat 
bencana, diharapkan kondisi tersebut dapat menjadi perhatian khusus sehingga mencegah terjadinya kerugian dan masalah yang berkelanjutan (Nurjannah, et al, 2012).

Aspek psikososial pada kondisi bencana merupakan sebuah pendekatan untuk mendorongnya ketahanan masyarakat dan individu yang menjadi korban bencana. Penanganannya sangat penting serta rumit, karena lebih berfokus pada psikis serta sosial manusia. Mental dan sosial merupakan bagian dari aspek psikososial yang berkaitan kepada pikiran, emosi dan kepribadian manusia. Pasca bencana Tsunami dan bencana Tamil Elam di Srilangka ditemukan 19 reaksi psikososial (Danvers, et al, 2006). Penelitian lain menjelaskan dampak psikososial dari bencana dapat diketahui berdasarkan tiga faktor yaitu faktor pra bencana, faktor bencana dan pasca bencana (Tomoko, 2009). Selain aspek psikososial, aspek spiritual juga mempengaruhi dampak terjadinya trauma akibat bencana.

Kejadian bencana dapat merubah pola spiritual seseorang, dapat bersifat positif maupun negatif. Aspek spiritual berkaitan dengan jati diri manusia, yang menghubungkan dengan Sang Pencipta. Aspek tersebut dapat digunakan dalam menghadapi permasalahan pada manusia serta kehidupannya. Kedua aspek tersebut tidak nampak, tidak dapat diraba, disentuh dan cukup rumit untuk dikaji serta diintervensi. Penelitian Kar (2010) menjelaskan spiritualitas yang sehat dapat dihubungkan dengan tingkat gejala dan masalah klinis yang lebih rendah pada masyarakat korban bencana. Sebagian besar negara percaya bahwa spiritualitas adalah aspek fundamental yang penting dan dapat digunakan saat terjadinya bencana (Benson, et al, 2016)

Nurcahyani, et al (2016) menjelaskan dampak negatif dari banjir yaitu menyebabkan kerugian fisik maupun psikis. Bentuk kerugian secara psikis yaitu trauma akibat peristiwa yang pernah dialami sebelumnya, dan konsisi tersebut sering ditemui pada warga yang menjadi korban bencana, atau yang sering dikenal dengan PTSD (Post Traumatic Stress Disorder). Ansietas, Post Traumatic Stress Disorder (PTSD) serta depresi merupakan masalah kejiwaan yang dapat ditimbul pada masyarakat baik sebagai korban secara langsung ataupun tidak langsung saat terjadinya bencana (Stuart, 2013).

Penelitian ini berfokus pada kepala keluarga yang mengalami korban bencana. Kepala keluarga merupakan pemimpin dalam keluarga yang bertanggungjawab memberikan keamanan dan kenyamanan anggota keluarganya terutama saat tempat tinggal berada di wilayah yang berpotensi bencana dan sangat diharapkan kemampuan yang memadai dalam melakukan pencegahan terjadinya dampak psikologis akibat bencana.

Penelitian yang dilakukan oleh Rufat, et all (2015) tentang kelompok sosial yang rentan terhadap banjir dengan menggunakan meta analisis terhadap 67 literatur tentang banjir didapatkan bahwa indikator dari masyarakat dalam menghadapi banjir diantaranya adalah usia, jenis kelamin dan status ekonomi yang meliputi pendidikan, pekerjaan dan penghasilan. Hal tersebut menunjukkan bahwa usia, jenis kelamin, pendidikan, penghasilan dan pekerjaan dapat berdampak pada kemampuan seseorang khususnya kepala keluarga yang bertanggung jawab atas anggota keluarganya yang lain dalam menghadapi bencana. Tujuan penelitian ini yaitu untuk mengidentifikasi hubungan aspek psikososial dengan aspek spiritual pada kejadian PTSD (Post Traumatic Stress Disorder) korban pasca banjir bandang di wilayah kota Garut Jawa Barat 


\section{METODE PENELITIAN}

Penelitian ini menggunakan desain metode kuantitatif non eksperimen dengan pendekatan cross sectional. Populasi dalam penelitian ini adalah seluruh kepala keluarga yang tinggal menetap di Kelurahan Haur Panggung Kecamatan Tarogong Kidul Kota Garut Jawa Barat. Metode pengambilan sampel yang digunakan dalam penelitian ini adalah non probability sampling yaitu teknik pengambilan sampel yang tidak dilakukan secara acak. Jumlah sampel digunakan sebanyak 150 kepala keluarga.

\section{HASIL PENELITIAN}

Karakteristik kepala keluarga berdasarkan usia dapat diketahui pada tabel 1 berikut ini :

Tabel 1.

Rerata Usia Kepala Keluarga di Kelurahan Haur Panggung Kecamatan Tarogong Kidul Kota Garut Jawa Barat Tahun $2018(n=150)$

\begin{tabular}{ccccc}
\hline Variabel & Mean & SD & Minimal-Maksimal & 95\% CI \\
\hline Usia & 37,88 & 10,55 & $19-67$ & $36,18-39,58$ \\
\hline
\end{tabular}

Berdasarkan hasil analisis pada tabel 1 dapat dijelaskan rerata usia kepala keluarga adalah 37,88 tahun dengan standar deviasi 10,55 tahun, dimana usia termuda kepala keluarga adalah 19 tahun dan usia tertua adalah 67 tahun. Hasil estimasi interval dapat disimpulkan bahwa 95\% diyakini rata-rata usia kepala keluarga berada pada rentang 36,18 sampai dengan 39,58 tahun.

Karakteristik responden berdasarkan Jenis Kelamin, Tingkat Pendidikan, Pekerjaan, Status Pernikahan dan Penghasilan dapat diketahui dari tabel 2 berikut ini :

Tabel 2.

Distribusi Frekuensi berdasarkan Jenis Kelamin, Tingkat Pendidikan, Pekerjaan, Status Pernikahan dan Penghasilan Kepala Keluarga di Kelurahan Haur Panggung Kecamatan Tarogong Kidul Kota Garut Jawa Barat Tahun $2018(n=150)$

\begin{tabular}{|c|c|c|}
\hline Variabel & Jumlah & Presentase \\
\hline \multicolumn{3}{|l|}{ Jenis Kelamin } \\
\hline 1. Laki-laki & 147 & 98 \\
\hline 2. Perempuan & 3 & 2 \\
\hline \multicolumn{3}{|l|}{ Pendidikan } \\
\hline 1. Tidak sekolah & 2 & 1,3 \\
\hline 2. SD & 76 & 50,7 \\
\hline 3. SMP & 53 & 35,3 \\
\hline 4. SMA & 19 & 12,7 \\
\hline Variabel Pekerjaan & Jumlah & Presentase \\
\hline 1. $\quad$ Tidak bekerja & 3 & 2 \\
\hline 2. Karyawan Swasta & 84 & 56 \\
\hline 3. Wiraswasta & 21 & 14 \\
\hline 4. Lainnya & 42 & 28 \\
\hline \multicolumn{3}{|l|}{ Penghasilan } \\
\hline $\begin{array}{l}\text { 1. Kurang dari } \\
\text { Rp } 1.000 .0000\end{array}$ & 119 & 79,3 \\
\hline $\begin{array}{ll}\text { 2. } & \mathrm{Rp} 1.000 .000- \\
& \mathrm{Rp} 2.000 .0000\end{array}$ & 28 & 18,7 \\
\hline $\begin{array}{l}\text { 3. Lebih dari } \\
\text { Rp } 3.000 .000\end{array}$ & 3 & 2 \\
\hline
\end{tabular}


Berdasarkan tabel 2 diketahui bahwa jenis kelamin responden lebih banyak laki-laki yaitu 147 orang (98\%) dibandingkan dengan perempuan yang berjumlah 3 orang (2\%). Berdasarkan pendidikan, responden sebagian besar berpendidikan SD berjumlah 76 orang $(50,7 \%)$, dan paling sedikit 2 orang (1,3\%) tidak sekolah. Untuk pekerjaan responden sebagian besar bekerja sebagai karyawan swasta sejumlah 84 orang (56\%) dan responden yang tidak bekerja sejumlah 3 orang (2\%). Sebagian besar penghasilan responden sekitar $<$ Rp 1.000.000 berjumlah 119 orang $(79,3 \%)$ dan yang berpenghasilan $\geq$ Rp 3.000 .0000 berjumlah 3 orang (2\%).

Gambaran Aspek Psikososial pada Kepala Keluarga dapat diketahui pada tabel 3 berikut ini :

Tabel 3.

Distribusi Frekuensi Aspek Psikososial pada Kepala Keluarga di Kelurahan Haur Panggung Kecamatan Tarogong Kidul Kota Garut Jawa Barat

Tahun $2018(\mathbf{n}=150)$

\begin{tabular}{ccc}
\hline Variabel & Jumlah & Presentase \\
\hline Perubahan psikososial kearah Positif & 70 & 46.7 \\
\hline Perubahan psikososial kearah Negatif & 80 & 53.3 \\
\hline
\end{tabular}

Berdasarkan tabel 4.3. diketahui bahwa kepala keluarga yang mengalami perubahan psikososial kearah negatif sebanyak 80 orang $(53,3 \%)$, sedangkan kepala keluarga yang mengalami perubahan psikososial kearah positif sebanyak 70 orang $(46,7 \%)$.

Gambaran Aspek Spiritual pada Kepala Keluarga dapat diketahui pada tabel 4 berikut ini :

Tabel 4.

Distribusi Frekuensi Aspek Spiritual pada Kepala Keluarga di Kelurahan Haur Panggung Kecamatan Tarogong Kidul Kota Garut Jawa Barat

Tahun $2018(n=150)$

\begin{tabular}{ccc}
\hline Variabel & Jumlah & Presentase \\
\hline Peningkatan Ibadah & $\mathbf{7 2}$ & $\mathbf{4 8}$ \\
\hline Penurunan Ibadah & $\mathbf{7 8}$ & 52 \\
\hline
\end{tabular}

Berdasarkan tabel 4.4. diketahui bahwa kepala keluarga yang mengalami penurunan kegiatan ibadah sebanyak 78 orang $(52 \%)$, sedangkan kepala keluarga yang mengalami peningkatan kegiatan ibadah sebanyak 72 orang $(48 \%)$.

Gambaran Kejadian PTSD pada Kepala Keluarga dapat diketahui pada tabel 5 berikut ini :

Tabel 5.

Distribusi Frekuensi Kejadian PTSD (Post Traumatic Stress Disorder) pada Kepala Keluarga di Kelurahan Haur Panggung Kecamatan Tarogong Kidul Kota Garut Jawa Barat Tahun 2018 (n=150)

\begin{tabular}{ccc}
\hline Variabel & Jumlah & Presentase \\
\hline Tidak mengalami PTSD & $\mathbf{7 4}$ & $\mathbf{4 9}$ \\
\hline Mengalami PTSD & $\mathbf{7 6}$ & $\mathbf{5 1}$ \\
\hline
\end{tabular}

Berdasarkan tabel 5 diketahui bahwa kepala keluarga yang mengalami gangguan PTSD sebanyak 76 orang (51\%), sedangkan kepala keluarga yang tidak mengalami gangguan PTSD sebanyak 74 orang (49\%).

Gambaran hubungan aspek psikososial dengan aspek spiritual pada kejadian PTSD (Post Traumatic Stress Disorder) korban pasca banjir bandang di wilayah kota Garut Jawa Barat dapat diketahui pada tabel 6 berikut ini: 


\section{Tabel 6}

Analisis Hubungan Aspek Psikososial dengan Aspek Spiritual pada Kejadian PTSD (Post Traumatic Stress Disorder) Korban Pasca Banjir Bandang di Wilayah Kota Garut Jawa Barat Tahun 2018 (n=150)

\begin{tabular}{|c|c|c|c|c|c|c|c|c|}
\hline \multirow{3}{*}{$\begin{array}{c}\text { Aspek } \\
\text { Psikososial }\end{array}$} & \multicolumn{4}{|c|}{ Aspek Spiritual } & \multicolumn{2}{|c|}{ Total } & \multirow[t]{3}{*}{ OR $(95 \%$ CI $)$} & \multirow[t]{3}{*}{ P Value } \\
\hline & \multicolumn{2}{|c|}{ Peningkatan } & \multicolumn{2}{|c|}{ Penurunan } & \multirow[b]{2}{*}{$\mathrm{N}$} & \multirow[b]{2}{*}{$\%$} & & \\
\hline & $\mathrm{n}$ & $\%$ & $\mathrm{~N}$ & $\%$ & & & & \\
\hline Positif & 22 & 31,4 & 48 & 68,6 & 70 & 100 & 2,47 & 0,011 \\
\hline Negatif & 52 & 65 & 28 & 35 & 80 & 100 & $1,25-4,88$ & \\
\hline Jumlah & 74 & 49,3 & 76 & 50,7 & 150 & 100 & & \\
\hline
\end{tabular}

Hubungan antara aspek psikososial dengan aspek spiritual dapat dilihat pada table 6 Hasil penelitian menunjukkan bahwa sebanyak 52 responden (65\%) mengalami aspek psikososial negatif dengan aspek spiritual yang meningkat Sedangkan diantara responden yang memiliki aspek psikososial positif dengan aspek spiritual meningkat sebanyak 22 responden (31,4\%). Hasil uji statistik diperoleh nilai $\mathrm{p}=0,011$, maka dapat disimpulkan ada perbedaan proporsi kejadian aspek spiritual meningkat diantara aspek psikososial positif dengan negatif (ada hubungan yang signifikan antara aspek psikososial dengan aspek spiritual). Dari hasil analisis diperoleh pula nilai $\mathrm{OR}=2,47$, artinya responden yang mengalami aspek psikososial negatif mempunyai peluang 2,47 kali mengalami kondisi aspek spiritual meningkat.

\section{PEMBAHASAN}

\section{Gambaran Karakteristik Kepala Keluarga}

Individu dapat memulihkan dan mempertahankan tingkat kesehatan fisik maupun emosional setelah mengalami suatu tragedi, trauma atau stressor yang bermakna dengan menggunakan faktor protektif yang ada yaitu faktor sosial budaya meliputi usia, jenis kelamin, pendidikan, penghasilan, pekerjaan, latar belakang budaya, keyakinan religi dan pengalaman sosialisasi yang dapat berdampak pada kemampuan seseorang dalam menghadapi bencana (Stuart, 2013).

Hasil penelitian yang didapat berdasarkan karakteristik usia yaitu data rerata usia kepala keluarga adalah 37,88 tahun dengan standar deviasi 10,55 tahun, dimana usia termuda kepala keluarga adalah 19 tahun dan usia tertua adalah 67 tahun. Hasil estimasi interval dapat disimpulkan bahwa 95\% diyakini rata-rata usia kepala keluarga berada pada rentang 36,18 sampai dengan 39,58 tahun.

Hasil penelitian diatas sejalan dengan hasil penelitian Ardalan, et al (2015) menunjukkan responden di Iran dalam menghadapi bencana ada pada rata-rata usia 44,14 tahun dengan rentang usia yang terbanyak sebesar $20 \%$ ada pada rata-rata usia 35-44 tahun. Maria, et al (2007) dalam penelitiannya menjelaskan responden yang berusia antara 26-65 tahun memiliki mean 35,75 yang lebih tinggi dari kelompok usia yang lain.

Usia 26-45 tahun berada pada rentang usia dewasa, dimana dengan bertambahnya usia maka perkembangan seseorangpun dapat berubah dan diharapkan dapat bertahan dalam menghadapi masalah kehidupan yang dihadapinya (Depkes, 2009). Pengalaman hidup dalam menjalankan tugas sesuai dengan usianya adalah salah satu tahapan usia perkembangan yang merupakan hasil proses kematangan dan belajar yang dipengaruhi oleh berbagai macam faktor (Nasir \& Muhith, 2011).

Pada batasan umur tertentu seseorang mengalami suatu perkembangan dan proses pematangan. Faktor usia sejalan dengan pengalaman individu, semakin tua usia seseorang, maka semakin banyak pengalaman yang 
dimiliki individu. Hal tersebut menunjukkan bahwa usia dewasa sudah memiliki tanggung jawab dan kemandirian yang tinggi terkait dengan kemampuan memenuhi sosial ekonomi dan memberikan dukungan serta mengambil keputusan. Tanggung jawab yang dijalankan pada pada usia dewasa sejalan dengan tugas dan tanggung jawab yang dijalankan oleh kepala keluarga yaitu mencari penghasilan, pendidik, pelindung, dan pemberi rasa aman, serta pengambil keputusan dalam keluarga. Pengambilan keputusan sangat diperlukan apabila keluarga bertempat tinggal di wilayah berpotensi bencana sehingga diperlukan motivasi yang sangat besar terutama oleh orang yang bertanggung jawab dalam keluarga yaitu kepala keluarga. Hasil penelitian yang didapat dengan karakteristik jenis kelamin yaitu laki-laki sebanyak 147 orang (98\%) dibandingkan dengan perempuan yang berjumlah 3 orang (2\%). Hal ini sejalan dengan penelitian yang dilakukan oleh Najafi, et al (2015) pada responden di Iran bahwa demografi yang menentukan dalam menghadapi bencana mayoritas lakilaki yaitu sebesar 62,3\% dibandingkan dengan responden yang berjenis kelamin wanita yaitu sebesar 37,7\%.

Penelitian Ali, M (2011) menunjukkan hasil yang sejalan bahwa jenis kelamin laki-laki memiliki korelasi dalam sifat kepemimpinan dan memiliki nilai $\mathrm{r}=0,557$, dimana laki-laki lebih mampu berhadapan dengan krisis. Kemampuan dan keterampilan individu untuk menghadapi bencana dapat dipengaruhi oleh beberapa hal diantaranya adalah jenis kelamin (Nurjannah, 2012). Reaksi terhadap situasi yang menuntut individu untuk bergerak cepat dan siap dalam menghadapi bencana akan mempengaruhi kemampuan dalam menghadapi bahaya banjir baik secara fisik maupun psikologis.

Berdasarkan hasil penelitian yang diperoleh menunjukkan pendidikan kepala keluarga sebagian besar berpendidikan SD berjumlah 76 orang $(50,7 \%)$, dan paling sedikit 2 orang (1,3\%) tidak sekolah. Penelitian ini sejalan dengan penelitian Rante (2012) yang menjelaskan distribusi responden berdasarkan tingkat pendidikan SD yang terbanyak sejumlah 19 orang. Berbanding terbalik dengan hasil penelitian Najafi M, et al (2015) bahwa demografi responden sebagian besar berpendidikan SMA sebesar 34,5\%. Jenjang pendidikan seseorang dapat mempengaruhi tingkat pengetahuan dalam memahami sesuatu. Individu yang memiliki mempunyai kognitif tinggi cenderung memiliki kemampuan yang lebih dalam menyelesaikan masalah yang dihadapi dan kemampuan diri pada penyelesaian masalah tersebut akan menghasilkan banyak ide yang kreatif sehingga individu mampu membuat rencana yang lebih baik kedepannya. Pendidikan yang dimiliki oleh individu akan mempengaruhi dalam mengambil keputusan menghadapi masalah atau krisis dalam hidupnya. Kemampuan kognitif erat kaitannya dengan pendidikan yang didapatkan oleh individu, dimana individu yang memiliki pendidikan yang tinggi cenderung memiliki kemampuan berpikir yang baik dalam menyelesaikan masalah yang dihadapi saat tempat tinggalnya berpotensi terjadi banjir. Hasil penelitian karakteristik pekerjaan didapatkan data sebagian besar kepala keluarga bekerja sebagai karyawan swasta sejumlah 84 orang (56\%) dan yang tidak bekerja sejumlah 3 orang (2\%). Hal tersebut juga didukung oleh penelitian Tomio, et al (2014) yang melakukan penelitian tentang kesiapsiagaan komunitas dan rumah tangga di Jepang, menunjukkan hasil pekerjaan kepala rumah tangga sebagian besar adalah karyawan yaitu 63\%. Hasil penelitian yang didapat berdasarkan penghasilan kepala keluarga yaitu penghasilan yang didapat < Rp 1.000 .000 berjumlah 119 orang $(79,3 \%)$ dan yang berpenghasilan $\geq \operatorname{Rp} 3.000 .0000$ berjumlah 3 orang (2\%). Hal ini sejalan dengan penelitian Najafi M, et al (2015) bahwa responden yang melakukan kesiapan bencana di Iran sebagian besar penghasilannya masih kategori rendah yaitu sebanyak $64,5 \%$. 
Hasil penelitian Dwi (2017) sejalan dengan hasil penelitian diatas yang menjelaskan bahwa pekerjaan kepala keluarga didominasi sebagai karyawan swasta sebanyak sebanyak 67 orang $(29,8 \%)$ dengan penghasilan ratarata kepala keluarga masih dibawah upah minimum propinsi karena pekerjaan yang mereka lakukan tidak berskala besar seperti menjadi karyawan toko/warung dan menjalankan usaha kecil dan menengah. Kemampuan kepala keluarga dalam menghadapi banjir dapat dipengaruhi oleh adanya karakteristik seperti jenis kelamin, usia, pendidikan, pekerjaan dan penghasilan sebagai faktor pendukung sebagai upaya dalam menghadapi bencana banjir. Penelitian yang dilakukan oleh Rufat, et all (2015) tentang kelompok sosial yang rentan terhadap banjir didapatkan bahwa indikator dari masyarakat yang melakukan kesiapan dalam menghadapi banjir diantaranya adalah usia, jenis kelamin dan status ekonomi yang meliputi pendidikan, pekerjaan dan penghasilan. Hal tersebut menunjukkan bahwa usia, jenis kelamin, pendidikan, penghasilan dan pekerjaan dapat berdampak pada kemampuan seseorang khususnya kepala keluarga yang bertanggung jawab atas anggota keluarganya yang lain dalam melakukan strategi kesiapan menghadapi banjir.

\section{Gambaran Aspek Psikososial Kepala Keluarga}

Hasil penelitian ini didapatkan data kepala keluarga yang mengalami aspek psikososial bersifat negatif sebanyak 80 orang $(53,3 \%)$, sedangkan kepala keluarga yang mengalami aspek psikososial bersifat positif sebanyak 70 orang (46,7\%). Sejalan dengan penelitian yang dilakukan oleh Hidayat (2010) menunjukkan adanya permasalahan psikososial yang dihadapi oleh kelompok korban bencana alam. Data dari 971 responden menunjukkan bahwa gangguan stress pasca trauma (post traumatic stress disorder) hanya sebesar 3,3 persen dari total responden. Sementara gangguan psikologis diperoleh dari hasil penelitian meliputi : kecemasan, depresi atau tertekan, psikosomatis serta masalah dalam penyesuaian diri.

Konsep psikososial terdiri dari dua hal, yaitu psiko dan sosial. Kata psiko mengacu pada jiwa, pikiran, emosi atau perasaan, perilaku, hal-hal yang diyakini, sikap, persepsi dan pemahaman akan diri. Kata sosial merujuk pada orang lain, tatanan sosial, norma, nilai aturan, sistem ekonomi, sistem kekerabatan, agama atau religi serta keyakinan yang berlaku dalam suatu masyarakat. Psikososial diartikan sebagai hubungan yang dinamis dalam interaksi antara manusia, dimana tingkah laku, pikiran dan emosi individu akan mempengaruhi dan dipengaruhi oleh orang lain atau pengalaman sosial.

Tujuan dukungan psikososial adalah mengembalikan individu atau keluarga atau kelompok pasca kejadian tertentu (bencana alam maupun bencana sosial) sehingga menjadi kuat secara individu atau kolektif ; berfungsi optimal, memiliki ketangguhan dalam menghadapi masalah; serta menjadi berdaya dan produktif dalam menjalani hidupnya. Menurut Stuart (2013) kemampuan atau strategi yang diperlukan untuk membantu dan menentukan apa yang harus dilakukan saat berada dalam situasi bahaya, dapat menggunakan keterampilan menyelesaikan masalah dengan mencari informasi, mengidentifikasi masalah, mempertimbangkan alternatif, mengimplementasikan rencana tindakan.

Menurut Zailani dkk (2009), respon psikologis masyarakat yang biasa terjadi saat berada pada situasi potensi terjadinya bencana adalah stres atau ansietas, disebabkan oleh lingkungan atau sekitar tempat tinggal yang berada di wilayah berpotensi bencana yang dapat mempengaruhi cara berfikir individu serta mengubah cara pandangnya dalam menghadapi masalah. 


\section{Gambaran Aspek Spiritual Kepala Keluarga}

Hasil penelitian ini memberikan gambaran kepala keluarga yang mengalami aspek spiritual rendah dengan penurunan ibadah sebanyak 78 orang (52\%), sedangkan kepala keluarga yang mengalami aspek spiritual tinggi dengan peningkatan ibadah sebanyak 72 orang (48\%). Berbeda dengan hasil penelitian Ariani, et all (2009) yang menunjukkan gambaran keyakinan spiritual korban pasca gempa bumiYogyakarta tahun 2009 sebanyak 79 responden $(86,8 \%)$ termasuk dalam kategori spiritual baik dan 12 responden $(13,2 \%)$ termasuk dalam kategori buruk.

Wiryasaputra (2008) menyatakan setelah melakukan proses normalisasi atau penyembuhan pada korban bencana maka akhirnya individu, keluarga atau komunitas tertentu dapat menerima kenyataan tentang bencana yang dialaminya. Menyerah dalam arti yang positif (tawakal), bukan putus asa merupakan titik tolak pertumbuhan baru. Dalam tahap tertentu mereka sudah siap membangun kembali lingkungannya. Pikiran mereka sudah jernih. Tenaga batin sosial, fisik dan spiritual, daya juang mereka sudah pulih. Bila masa-masa penampungan tidak diperhatikan maka cenderung menghambat proses pemulihan dari traumatik dan perkembangannya bahkan bisa terjadi cacat secara mental.

\section{Gambaran Kejadian PTSD}

Berdasarkan hasil penelitian yang didapat kepala keluarga yang mengalami gangguan PTSD sebanyak 76 orang (51\%), sedangkan kepala keluarga yang tidak mengalami gangguan PTSD sebanyak 74 orang (49\%). Sejalan dengan hasil penelitian Dwi,et all (2017) menunjukkan sebagian besar responden mempunyai kecenderungan mengalami PTSD sebanyak 51,2\%.

Bencana dapat menyebabkan individu dan keluarga mengalami gangguan atau masalah secara fisik dan mental yang bersifat traumatik, karena bencana akan selalu menimbulkan kerugian dan penderitaan serta mempengaruhi aspek-aspek kehidupan sehingga diperlukan cara-cara untuk mencegah dan mengelolanya (Keliat, 2011). Masalah kejiwaan yang dapat timbul pada masyarakat baik sebagai korban langsung dan korban tidak langsung saat bencana adalah gangguan ansietas, panik, Post Traumatic Stress Disorder (PTSD) dan Depresi (Stuart, 2013).

Hal tersebut biasa ditemukan dan responnya bervariasi pada setiap individu, dikarenakan adanya perbedaan pada kemampuan individu dalam mengurangi ketegangan yang menimbulkan ketidakseimbangan emosional dan pegalaman yang bersifat traumatik. Individu yang mengalami bencana dapat dipastikan akan mengalami trauma yang dikenal dengan sebutan Gangguan Stres Pasca Trauma atau Acute Stress Reaction.

\section{Hubungan aspek psikososial dengan aspek spiritual}

Hasil penelitian hubungan antara aspek psikososial dengan aspek spiritual menunjukkan bahwa sebanyak 52 responden $(65 \%)$ mengalami aspek psikososial negatif dengan aspek spiritual yang tinggi. Sedangkan diantara responden yang memiliki aspek psikososial positif dengan aspek spiritual tinggi sebanyak 22 responden $(31,4 \%)$. Hasil uji statistik diperoleh nilai $\mathrm{p}=0,011$, maka dapat disimpulkan ada perbedaan proporsi kejadian aspek spiritual tinggi diantara aspek psikososial positif dengan negatif (ada hubungan yang signifikan antara aspek psikososial dengan aspek spiritual). Dari hasil analisis diperoleh pula nilai $\mathrm{OR}=2,47$, artinya responden 
yang mengalami aspek psikososial negatif mempunyai peluang 2,47 kali mengalami kondisi aspek spiritual tinggi.

Crabtree (2012) telah melakukan telaah terhadap 34 literatur yang berfokus dampak banjir pada kesehatan mental menunjukkan hasil bahwa PTSD ditemukan 62\% di Venezuela, di Nicaragua $81 \%$ mengalami depresi, 8.5\% beresiko bunuh diri di China, di India $84 \%$ menunjukkan gejala ansietas dan dampak lain seperti ketergantungan alkohol 5.8\% di Honduras dan yang mengalami Acut Stress Disorder 2.2\% di Myanmar. Sejalan dengan pendapat Veenema (2009) yaitu peristiwa yang berhubungan dengan bencana dapat menyebabkan respon yang berbeda-beda bagi individu ketika peristiwa bencana tersebut menyebabkan ancaman kematian, luka serius atau gangguan pada integritas fisik dari individu sehingga dampak individu terhadap bencana terbagi atas respon fisiologis berupa gangguan fisik maupun respon psikososial berupa stres traumatik ataupun ansietas. Hasil penelitian Johannesdottir dan Gisladottir (2010) pada 28 orang partisipan yang tinggal dan bekerja disepanjang jalur vulkanik di Iceland Selatan dengan wawancara mendalam mengungkapkan bahwa mereka memiliki kekhawatiran dan ketakutan bila terjadi bencana berulang karena tidak mengetahui tindakan apa yang harus dilakukan. Kemampuan individu atau komunitas dalam melalui fase bencana tidak selalu berurutan karena keunikan masing-masing dan faktor lain seperti ketahanan psikologis, dukungan sosial dan sumber finansial.

Manusia adalah makhluk biopsikososial yang unik dan menerapkan system terbuka serta saling berinteraksi. Manusia selaulu berusaha untuk mempertahankan keseimbangan hidupnya. Keseimbangan yang dipertahankan oleh setiap individu untuk dapat menyesuaikan diri dengan lingkungannya, keadaan ini disebut dengan sehat. Sedangkan seseorang dikatakan sakit apabila gagal dalam mempertahankan keseimbangan diri dan lingkungannya.

Menurut Benseller (2005), gangguan stress pascatrauma nampak setelah sebulan atau setahun setelah bencana dengan memperlihatkan ciri selalu diburu oleh ketakutan yang berhubungan dengan bencana yang dialaminya seperti ketakutan akan berpisah dari orangtua atau keluarganya untuk selama-lamanya dan sering mengalami gangguan dalam tidur dengan mimpi-mimpi buruk, menjerit, dan mengompol di tempat tidur. Akumulasi trauma psikososial itu bisa berupa reaksi fisik maupun gejala-gejala psikis seperti rasa mual, murung, pendiam, mimpi buruk, kecemasan, merasa terancam, serta hilangnya harapan hidup. Bencana banjir mengakibatkan dampak yang dapat merugikan dikehidupan masyarakat yang dapat berupa tidak hanya kerugian fisiknamun juga kerugian psikologis yaitu terganggunya kondisi mental karena kehilangan harta benda dan keluarga akibat bencana (Nurjannah, dkk, 2012), sehingga memerlukan perhatian khusus berupa upaya atau kegiatan antisipatif supaya tidak menimbulkan dampak bagi kehidupan masyarakat selanjutnya.

Hasil penelitian Johannesdottir dan Gisladottir (2010) pada 28 orang partisipan yang tinggal dan bekerja disepanjang jalur vulkanik di Iceland Selatan dengan wawancara mendalam mengungkapkan bahwa mereka memiliki kekhawatiran dan ketakutan bila terjadi bencana berulang karena tidak mengetahui tindakan apa yang harus dilakukan. Menurut Kaakinen (2010), peran dan fungsi keluarga saat terjadi bencana tergantung dari fase bencana yang dialami yaitu fase pra bencana, saat bencana dan setelah bencana. 


\section{KESIMPULAN DAN REKOMENDASI}

Hasil penelitian yang didapat berdasarkan karakteristik usia yaitu kepala keluarga berada pada fase usia dewasa, dengan mayoritas jenis kelamin laki-laki. Kepala keluarga memiliki pendidikan paling banyak sampai dengan SD dengan karakteristik pekerjaan sebagai karyawan swasta serta memiliki penghasilan dibawah UMR atau berpenghasilan rendah. Aspek psikososial yang dialami oleh keluarga sebagian besar bersifat negatif dengan aspek spiritual bersikap rendah. Kepala keluarga banyak yang mengalami gangguan PTSD, sehingga dapat disimpulkan adanya hubungan yang signifikan antara aspek psikososial dengan aspek spiritual. Perlu adanya keterlibatan berbagai pihak dalam memberikan Psikososial Support Program sebagai solusi pemulihan aspek psikososial dan spiritual pada masyarakat pasca bencana. Institusi pendidikan keperawatan dapat mempertahankan dan mengembangkan pengetahuan tentang Disaster Nursing khususnya pada fase pra bencana yang tidak hanya memperhatikan masalah fisik namun juga masalah psikososial dalam upaya mengurangi dampak yang memanjang khusunya psikososial saat menghadapi bencana.

\section{REFERENSI}

1. Badan Nasional Penanggulangan Bencana. (2017). Data Kebencanaan (diakses melalui www.bnpb.go.id diakses pada tanggal 9 Mei 2017).

2. Benson, Perry, W, Leola Dyrud Furman, et al. (2016). Spiritually Sensitive Social Work with Victims of Natural Disaster and Terrorism. British Journal of Social Work.

3. BNPB (2016). Bencana Alam di Indonesia.http://www.bnpb.go.id.

4. Budiarto, T. (2010). Penanganan Darurat Bencana Gempabumi Di Kabupaten Lombok Utara. Jakarta: BNPB.

5. Danvers, Bhugra, and Ommeren, M, V. (2006). Mental Health Psychososial Support and The Tsunami. Journal International Review of Psychiatric. Vol.18

6. Erwina, Ira, Keliat, Budi \& Nasution Yusron. (2010). Pengaruh Cognitive Behaviour Therapy terhadap PTSD pada Pendidikan Pasca Gempa di Kota Padang Provinsi Sumatera Barat tahun 2010. Tesis Fakultas Ilmu Keperawatan Universitas Indonesia.

7. Harjadi Prih, Mezak A Ratag, Dwikorita Karnawati, Samsul Rizal, Surono, Sutardi, Triwibowo, Hermono, Atik Warsiati, Yusharmen, Pariatmono, Sugeng Triatmono, B. Wisnu Widjaja. (2007). Pengenalan Karakteristik Bencana dan Upaya Mitigasinya Di Indonesia.Direktorat Mitigasi : Jakarta Pusat.

8. Kaakinen, J.R, et all (2010). Family Health Care Nursing. 4th edition. Philadelphia: F.A .Davis Company

9. Kar, Nilamadhab. (2010). Indian Research on Disaster and Mental Health. Indian Journal of Psychiatric Society.

10. Keliat, B.A., Daulima, N.H.C., \& Farida, P. (2011). Manajemen Keperawatan Psikososial dan Kader Kesehatan Jiwa CMHN (Intermediate Course). Jakarta: EGC. 
11. Murray, B., et al. (2011). The Role Preperedness and Management of Nurses During Disaster. International Scientific Research Journal 3(4). 269-294.

12. National Center For PTSD. (2012). Spiritually and Trauma Profesionals Working Together. U.S Department of Veterans Affairs.

13. Nurjanah., Sugiharto, R., Kuswanda, Dede., Siswanto., Adikoesoemoyo. (2012). Manajemen Bencana. Alfa Beta; Bandung.

14. Peraturan Pemerintah RI Nomor 21 (2008). Penyelenggaraan Penanggulangan Bencana. http://www.bnpb.go.id.

15. Rufat, S., et al (2015). Social Vulnerability to Floods: Review of Case Studies and Implications for Measurement. International Journal of Disaster Risk Reduction. 14(2015). 470-486.

16. Schneid, T.D and Collins, L, (2012). Disaster Management and Preparedness. London : Lewis Publishers.

17. Stuart, G.W. (2013). Buku Saku Keperawatan Jiwa. ed 5. EGC: Jakarta

18. Tomoko, O. (2009). E-learning Disaster. Jakarta: FIK UI.

19. Widyatmoko, S. (2008). Setelah Musibah. Maret 15. 2017. http://www.penapendidikan.com/setelah musibah/ 